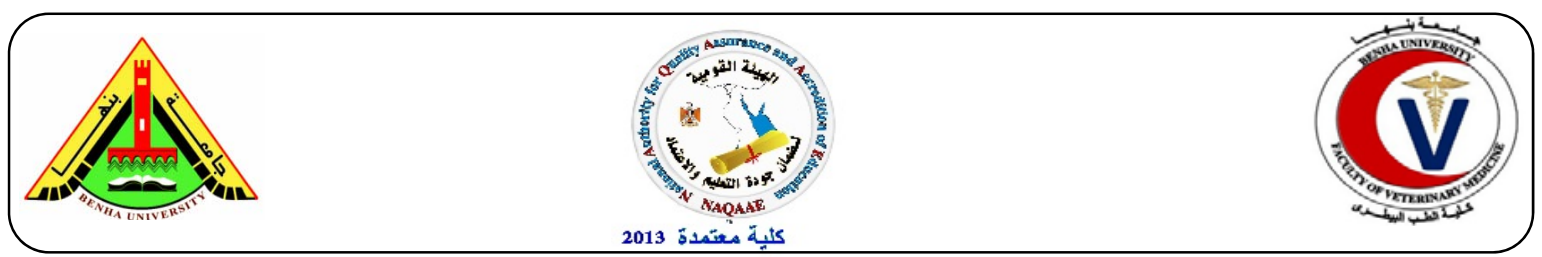

\title{
Effect of Spirulina platensis as feed supplement on growth performance, immune response and antioxidant status of mono-sex Nile Tilapia (Oreochromis niloticus)
}

Shimaa A. Amer

Department of Nutrition \& Clinical Nutrition, Faculty of Veterinary Medicine, Zagazig University, Egypt.

\begin{abstract}
A B S T R A C T
To evaluate the effect of Spirulina platensis inclusion in diets for Nile tilapia fingerlings, a completely randomized experimental design was developed with 4 treatments and three replicates. Diets with 4 inclusion levels (control diet (Sp0), 0.5\% (Sp0.5), 1\% (Sp1) and 1.5\% (Sp1.5)) were prepared. 180 Nile tilapia fingerlings with average initial weight of $8.46 \pm 0.17 \mathrm{~g}$ were assigned to twelve experimental tanks. The experiment lasted for ten weeks. At the end of the experiment; growth performance, the whole body composition was determined and serum samples for lysozyme, IgG, IgM values and catalase activity were collected and antioxidant status of Nile tilapia muscle were determined. The results showed that group supplemented with $1 \%$ S. Platensis have higher body weight and lower FCR than the control group and other groups. S. platensis inclusion increased activity of glutathione reductase, and reduce MDA formation. Levels of lysozyme, IgG and catalase activity were higher in S. platensis supplemented groups but don't have significant effect on IgM level. In conclusion, Spirulina platensis supplementation increased antioxidant protective capacities. It also affected some innate and humoral immunity parameters as well as don't have negative effect on fish growth.
\end{abstract}

Keywords: Nile tilapia, Spirulina platensis, Growth performance, Antioxidant status, innate and humoral immunity.

(http://www.bvmj.bu.edu.eg)

(BVMJ-30(1): 1-10, 2016)

\section{INTRODUCTION}

$\mathrm{S}$ platensis is a photosynthetic, filamentous, blue-green microalgae and is generally regarded as a rich source of vitamins, essential amino acids, minerals, essential fatty acids ( $\gamma$-linolenic acid), and antioxidant pigments such as carotenoids and phycocyanin (JaimeCeballos et al., 2006). Recently, Spirulina has been speculated to be associated with modulation of the host immune system (Hironobu et al., 2006). As feed additives, dried algae improve growth, feed efficiency, carcass quality, and physiological response to stress and disease in several species of fish (Mustafa and Nakagawa, 1995). In addition, it is effective as an immunomodulator (Takeuchi et al., 2002). It has been confirmed that the addition of small amounts of algae to fish feed can exert pronounced effects on growth, lipid metabolism, body composition, and disease resistance (Mustafa et al., 1994). Feeding S. platensis activated protein synthesis and somatic growth in red sea bream (Mustafa et al., 1994), guppy (Dernekbasi et al., 2010), African sharptooth catfish (Promya and Chitmanat, 2011), and Indian carps (Nandeesha et al., 2001). Hence, S. platensis may have potential to be used as a natural feed supplement for increasing fish growth. The use of antioxidant nutritional and food supplements has been the subject of many studies (Estrada et al., 2001), with several findings that phenolic compounds can not only increase the shelf-life of foods 
but also act as antioxidants in many biological systems (Milié et al., 1998). Phenolic compounds have been extensively studied for their antioxidant properties not only in fruits and vegetables (Amaral et al., 1995; Frankel et al., 1995; Yen and Chen, 1995; Yoshino and Murakami, 1995; Duval and Shetty, 2001) but also in cyanobacteria. For example, Miranda et al. (1998) studied the antioxidant activity of carotenoids, phenolics and tocopherols extracted from S. maxima and found that the phenolic compounds responsible for the antioxidant properties of the S. maxima extracts were organic acids (caffeic, chlorogenic, quimic, salicylic, synaptic and trans-cinnamic) which acted individually or synergistically, while Estrada et al. (2001) demonstrated the antioxidant activity of the phycobiliproteins, phycocyanin and alophycocyanin present in Spirulina biomass.

Therefore, the main objective of the present study is to evaluate the effect of Spirulina platensis meal, as feed additive on growth performance, the whole body composition, lysozyme, $\operatorname{IgG}, \operatorname{IgM}$ values and catalase activity in serum and antioxidant status in Nile tilapia muscle.

\section{MATERIAL \&METHODS}

\subsection{Fish and experimental protocol}

A total of 180 mono-sex Nile tilapia fingerlings $(8.46 \pm 0.17 \mathrm{~g})$ were randomly allocated into 4 different treatments with three replicates each. All subgroups were housed in separate $100 \mathrm{~L}$ fiberglass tanks (15 fingerlings per replication). The whole water of the tanks was exchanged with fresh water daily. Water quality parameters were checked three times per week after the first feeding according to the methods of APHA (1992). Those parameters were kept within optimal rang for Nile tilapia; temperature $24 \pm 2{ }^{\circ} \mathrm{C}, \mathrm{pH} 8.0 \pm 1$, Ammonia $0.03 \pm 0.01$ $\mathrm{mg} / \mathrm{L}$ and dissolved oxygen (DO) $4 \pm 1$ $\mathrm{mg} / \mathrm{L}$.

\subsection{Experimental design, diets and performance}

Four artificial diets were formulated using four levels of microalgae $\mathrm{S}$. platensis $(0$ (Sp0), 0.5 (Sp0.5), 1 (Sp1) and 1. 5\% (Sp1.5)). Zero percentage was designated as a control diet. The proximate composition of the experimental diets showed in table no. 1 and the composition of Spirulina platensis showed in table no. 2. Dietary feed ingredients were ground using a laboratory grinder, and then blended into a homogenous doughy matter by adding water, which pelleted by pressing through a $4 \mathrm{~mm}$ die in a grinding machine. The pellets were then stored in plastic containers at -30 ${ }^{\circ} \mathrm{C}$ until use. The chemical analysis of ingredients, diets and fish samples were analyzed according to NRC (1993) methods for dry matter, crude protein, ether extract, crude fiber and ash. Digestible energy (DE) contents of the experimental diets were calculated based on values of protein 3.5 $\mathrm{kcal} / \mathrm{gm}$, fat $8.1 \mathrm{kcal} / \mathrm{gm}, \mathrm{NFE} 2.5 \mathrm{kcal} / \mathrm{gm}$ according to (Santiago et al., 1982). All fish were fed the control diet during the first 7 days after stocking to adapt them to feeding and handling practices. After that, the fish were fed the experimental diets. Fish were fed by hand to apparent satiation three times a day for 75 days at a rate of $4 \%$ of body weight. Fish were individually weighed every 2 weeks following a 14-h starvation period. Fish body weight, fish size and feed intake were taken every 2 weeks. Mortality was recorded daily. At the end of the trial (75 days), live weight gain and feed efficiency were obtained.

\subsubsection{Measurement of growth performance}

Total weight gain, average daily gain, specific growth rate, feed conversion ratio was calculated according to Recker, (1975) and Castell and Tiews, (1980). Total gain $(\mathrm{g} /$ fish $)=(\mathrm{WT}-\mathrm{WI})$. Where: WT: Final weight of fish in grams and WI: Initial weight of fish in grams.

Average daily gain $(\mathrm{ADG})(\mathrm{g} / \mathrm{fish} /$ day $)=$ total gain / duration period in day Specific growth rate $(\mathrm{SGR}, \% /$ day $)=100 \times(\ln \mathrm{WT}$ - $\ln$ WI) / duration period/day. Where $\ln$ is the natural $\log$. 


\subsubsection{Measurement of feed and nutrient utilization}

Total feed intake (FI): The diet was provided regularly daily as a percent of body weight and feed intake was calculated as the total weight diet offered in a given period divided by the number of survival fish. Feed conversion ratio $(\mathrm{FCR})=$ dry matter intake $(\mathrm{g}) /$ total gain $(\mathrm{g})$. Protein efficiency ratio (PER) It was calculated according to Stuart and Hung (1989). PER $=$ total gain $(\mathrm{g}) /$ protein intake $(\mathrm{g})$. Protein retention efficiency (PRE): It was calculated according to Zehra and Khan (2011). PRE, $\%=$ Protein gain / Protein intake * 100

\subsubsection{Sampling}

At the end of the experiment, blood samples (6 fish/replicate) were collected from heart puncture then centrifuged at $3500 \mathrm{rpm}$ for 15 min to obtain serum for determination of lysozyme, IgG, IgM values and catalase activity. Six fish per replicate were sampled and stored frozen $\left(-25^{\circ} \mathrm{C}\right)$ for further tissue analysis.

\subsection{Antioxidant status determination}

To determine the effect of the different dietary treatments on antioxidant status, muscle samples from 12 fish per treatment were collected at the end of the experimental period and levels of glutathione reductase as well as malondialdehyde values were evaluated after freezing at $-25^{\circ} \mathrm{C}$ according to Giannenas et al. (2011). Muscle samples were assayed for the levels of malondialdehyde (MDA) and glutathione reductase (GR) according to the procedures described below. All samples were immediately frozen at $-25{ }^{\circ} \mathrm{C}$ after collection and were analysed within a month of collection.

\subsubsection{Lipid peroxidation assay}

Malondialdehyde (MDA) was used as a marker of lipid peroxidation. A quantity of $14 \mu \mathrm{l}$ of butylated hydroxytoluene and 1400 $\mu l$ of a mixture of $0.375 \%$ thiobarbituric acid and $0.9 \%$ trichloroacetic acid in $0.25 \mathrm{~N}$ $\mathrm{HCl}$ was added to $100 \mu \mathrm{l}$ of tissue homogenate; samples $(0.5 \mathrm{~g})$ were placed in tubes and homogenized. The samples were incubated at $100{ }^{\circ} \mathrm{C}$ in a water bath for 15 min, centrifuged at $13,000 \mathrm{~g}$ for $5 \mathrm{~min}$ and the absorbance of the supernatant was read at $532 \mathrm{~nm}$ on the spectrophotometer. MDA concentrations in the samples were plotted against a reference curve made using known amounts of MDA and expressed as $\mathrm{nmol} / \mathrm{mg}$ of protein.

\subsubsection{Assay of glutathione reductase (GR)}

GR activity was determined, in brief, by mixing $50 \mu \mathrm{l}$ of $25 \mathrm{mM}$ GSSG and $10 \mu \mathrm{l}$ of sample to $890 \mu \mathrm{l}$ of $143 \mathrm{mM}$ sodium phosphate buffer ( $\mathrm{pH} 7.5$ ) containing $1 \mathrm{mM}$ EDTA. The reaction was initiated by adding $50 \mu \mathrm{l}$ of $3 \mathrm{mM}$ NADPH and the absorbance decrease rate was recorded using a spectrophotometer at $340 \mathrm{~nm}$ for $3 \mathrm{~min}$ against blank containing all components except GSSG. GR activity was expressed as units/mg protein (extinction coefficient for $\mathrm{NADPH}=0.00622 \mathrm{nmol} / \mathrm{min} / \mathrm{ml}, 1$ unit $=$ the amount of NADPH oxidized $/ \mathrm{min} / \mathrm{ml}$ ).

\subsection{Detection of lysozyme, IgG, IgM values and catalase activity in serum}

Lysozyme activity was measured by a modified assay according to (Lie et al., 1989) based on the lysis of the lysozymesensitive Gram positive bacterium Micrococcus lysodeikticus (Sigma-Aldrich Ltd., Athens, Greece). Lyophilized bacteria $(0.2 \mathrm{mg} / \mathrm{ml})$ suspended in $100 \mu \mathrm{l}$ of $0.05 \mathrm{M}$ sodium phosphate buffer, $\mathrm{pH}$ 6.2, were added to $100 \mu \mathrm{l}$ of serially diluted serum and the reduction in absorbance at $450 \mathrm{~nm}$ was measured after 5 and $15 \mathrm{~min}$ at $25^{\circ} \mathrm{C}$. One unit of lysozyme activity was defined as a reduction in absorbance of $0.001 / \mathrm{min}$. Quantification of lysozyme activity in serum was obtained from a standard curve made with chicken egg white lysozyme (Sigma). Catalase activity was measured by an assay of hydrogen peroxide based on formation of its stable complex with ammonium molybdate (Goth, 1991). In brief, $10 \mu \mathrm{l}$ of serum was incubated in $1 \mathrm{ml}$ 
reaction mixture containing $65 \mathrm{mM}$ hydrogen peroxide in $60 \mathrm{mM}$ sodium phosphate buffer, $\mathrm{pH} 7.5$ at room temperature for $4 \mathrm{~min}$. The reaction was stopped with $1 \mathrm{ml}$ of $32.4 \mathrm{mM}$ ammonium molybdate and the sample was measured in a spectrophotometer at $405 \mathrm{~nm}$. The absorbance found was plotted against a reference curve of known concentrations of hydrogen peroxide. IgM value determined by IgM ELISA kit (Catalog No: MBS700823). This assay employs the competitive inhibition enzyme immunoassay technique. The microtiter plate provided in this kit has been precoated with goat-anti-rabbit antibody. Standards or samples are added to the appropriate microtiter plate wells with an antibody specific for IgM and Horseradish Peroxidase (HRP) conjugated IgM. The competitive inhibition reaction is launched between with HRP labeled IgM and unlabeled IgM with the antibody. A substrate solution is added to the wells and the color develops in opposite to the amount of $\operatorname{IgM}$ in the sample. The color development is stopped and the intensity of the color is measured.

IgG determined by IgG ELISA kit (Catalog No: MBS043814). This Quantitative Sandwich ELISA kit is only for in vitro research use only, not for drug, household, therapeutic or diagnostic applications! This kit is intended to be used for determination the level of IgG (hereafter termed "analyte") in undiluted original Fish body fluids, tissue homogenates, secretions or feces samples. This kit is not suitable for assaying nonbiological sources of substances.

\subsection{Statistical analysis}

All data were expressed as the mean \pm SD. All data were verified for normality after transformation (ASIN). One-way ANOVA was used to determine the effects of $\mathrm{S}$. platensis on growth performance, immune and antioxidant status using SPSS version 17 for Windows (SPSS, Inc., Chicago, IL, USA). Duncan's multiple range test was used to compare differences between the means at $5 \%$ probability.

\section{RESULTS}

\subsection{Growth performance}

Growth performance and feed utilization of Nile tilapia after 75 days of feeding on experimental diets are presented in Table 3 . There were no significant differences $(P>0.05)$ in weight gain between fish fed $S$. Platensis supplements and the control diet, although group supplemented with $1 \% S$. Platensis have higher body weight than the control group and other groups. There was significant decrease in FCR in group supplemented with $1 \%$ S. Platensis than the control group and other groups $(\mathrm{P}<0.05)$. There was significant increase in PER in group supplemented with $1 \%$ S. Platensis than the control group and other groups. There were no significant differences in total feed intake, SGR $\%$ between control group and other groups.

3.2. Moisture, crude protein, crude lipid and ash of the whole fish.

In terms of body composition, no significant difference in DM, protein and ash content among treatments $(P>0.05)$, but there was significant decrease in fat content of the fish between control group and other groups as shown in table (4).

\subsection{Antioxidant status}

S. Platensis supplementation decreased significantly $(P<0.05) \quad$ malondialdehyde formation compared to control group. Activity of glutathione reductase enzyme significantly higher in $S$. Platensis supplemented groups compared to control $(P<0.05)$ (Table 5).

\subsection{Blood parameters}

Level of Catalase, Lysozyme and IgG value were found to be higher $S$. Platensis supplemented groups compared to control group $(P<0.05)$, while IgM value not 
Table 1: The proximate composition of the experimental diets

\begin{tabular}{lcccc}
\hline Ingredient & \multicolumn{4}{c}{ Dietary groups } \\
& $\mathrm{Sp} 0$ & $\mathrm{Sp} 0.5$ & $\mathrm{Sp} 1$ & $\mathrm{Sp} 1.5$ \\
\hline Fish meal & 15 & 14.5 & 14 & 13.5 \\
Soybean meal & 27.6 & 27.6 & 27.6 & 27.6 \\
Yellow corn & 26 & 26 & 26 & 26 \\
Corn gluten & 12 & 12 & 12 & 12 \\
Wheat bran & 12.7 & 12.7 & 12.7 & 12.7 \\
Soy oil & 5.5 & 5.5 & 5.5 & 5.5 \\
S. platensis meal & 0 & 0.5 & 1.0 & 1.5 \\
Vit. \& mineral premix $^{2}$ & 1.2 & 1.2 & 1.2 & 1.2 \\
Total & 100 & 100 & 100 & 100 \\
Chemical composition & 1 \\
DM & & & & \\
Crude protein & 91.67 & 91.67 & 92.05 & 92.05 \\
Lipid $_{\text {Ash }}$ & 33.41 & 33.40 & 33.38 & 33.37 \\
DE $^{3}$ & 9.35 & 9.35 & 9.35 & 9.35 \\
\hline
\end{tabular}

${ }^{1}$ According to NRC (1993). ${ }^{2}$ Each $1 \mathrm{~kg}$ of premix contain: vit A $550000 \mathrm{IU}$, vit D $110000 \mathrm{IU}$, vit E $11000 \mathrm{mg}$, vit K $484 \mathrm{mg}$, vit C 50 gm, vit B1 440 mg, vit B2 $660 \mathrm{mg}$, vit B3 $13200 \mathrm{mg}$, vit B5 $1100 \mathrm{mg}$, vit B6 1045 mg, vit B9 $55 \mathrm{mg}$, Choline $110000 \mathrm{mg}$, Biotine $6.6 \mathrm{mg}$, iron $6.6 \mathrm{gm}$, copper $330 \mathrm{mg}$, Mn $1320 \mathrm{mg}$, Zn $6.6 \mathrm{gm}, \mathrm{Se} 44 \mathrm{mg}$, iodine $110 \mathrm{mg} .{ }^{3}$ Digestible energy (DE) contents of the experimental diets were calculated based on values of protein $3.5 \mathrm{kcal} / \mathrm{gm}$, fat $8.1 \mathrm{kcal} / \mathrm{gm}$, NFE $2.5 \mathrm{kcal} / \mathrm{gm}$. According to Santiago et al., (1982).

Table 2: The proximate composition of S. platensis

\begin{tabular}{ll}
\hline proximate composition & Ingredient (S. platensis) \\
\hline Dry matter & $92.69 \%$ \\
crude protein & $63 \%$ \\
Crude lipid & $12 \%$ \\
\hline
\end{tabular}

Means within the same row carrying different superscripts are significantly different at $(P \leq 0.05)$

Table 3: Effect of S. Platensis supplementation on growth performance of Nile Tilapia fingerlings

\begin{tabular}{lcccc}
\hline & Sp0 & Sp0.5 & Sp1 & Sp1.5 \\
\hline Initial BW(g) & $8.45 \pm 0.07^{\mathrm{a}}$ & $8.54 \pm 0.05^{\mathrm{a}}$ & $8.45 \pm .08^{\mathrm{a}}$ & $8.39 \pm .07^{\mathrm{a}}$ \\
FBW (g) & $18.44 \pm 0.08^{\mathrm{ab}}$ & $18.66 \pm 0.54^{\mathrm{ab}}$ & $19.12 \pm 0.43^{\mathrm{a}}$ & $17.68 \pm 0.42^{\mathrm{b}}$ \\
TWG (g) & $9.99 \pm 0.15^{\mathrm{a}}$ & $10.11 \pm 0.59^{\mathrm{a}}$ & $10.66 \pm 0.43^{\mathrm{a}}$ & $9.29 \pm 0.35^{\mathrm{a}}$ \\
ADWG (g) & $0.133 \pm 0.002^{\mathrm{a}}$ & $0.134 \pm 0.007^{\mathrm{a}}$ & $0.142 \pm 0.005^{\mathrm{a}}$ & $0.124 \pm 0.004^{\mathrm{a}}$ \\
TFI (g) & $22.96 \pm 0.12^{\mathrm{a}}$ & $22.09 \pm 0.86^{\mathrm{a}}$ & $22.13 \pm 0.55^{\mathrm{a}}$ & $21.93 \pm 0.23^{\mathrm{a}}$ \\
FCR & $2.29 \pm 0.02^{\mathrm{a}}$ & $2.19 \pm 0.08^{\mathrm{ab}}$ & $2.07 \pm 0.03^{\mathrm{b}}$ & $2.36 \pm 0.07^{\mathrm{a}}$ \\
SGR \% & $13.32 \pm 0.21^{\mathrm{a}}$ & $13.49 \pm 0.79^{\mathrm{a}}$ & $14.22 \pm 0.58^{\mathrm{a}}$ & $12.39 \pm 0.47^{\mathrm{a}}$ \\
PER & $1.24 \pm 0.01^{\mathrm{b}}$ & $1.31 \pm 0.05^{\mathrm{ab}}$ & $1.37 \pm 0.02^{\mathrm{a}}$ & $1.20 \pm 0.03^{\mathrm{b}}$ \\
\hline
\end{tabular}

Means within the same row carrying different superscripts are significantly different at $(P \leq 0.05)$ 
Table 4: Effect of S. Platensis supplementation on whole body composition of Nile tilapia fingerlings

\begin{tabular}{ccccc}
\hline & Sp0 & Sp0.5 & Sp1 & Sp1.5 \\
\hline DM \% & $22.46 \pm 0.72^{\text {a }}$ & $22.99 \pm 0.73^{\text {a }}$ & $23.74 \pm 0.32^{\text {a }}$ & $22.64 \pm 0.39^{\mathrm{a}}$ \\
Protein \% & $62.49 \pm 1.27^{\text {a }}$ & $64.78 \pm 1.34^{\mathrm{a}}$ & $66.95 \pm .88^{\mathrm{a}}$ & $64.29 \pm 3.09^{\mathrm{a}}$ \\
Lipid \% & $11.66 \pm .33^{\mathrm{a}}$ & $9.33 \pm 0.33^{\mathrm{b}}$ & $9.66 \pm 0.88^{\mathrm{b}}$ & $9.16 \pm 0.44^{\mathrm{b}}$ \\
Ash \% & $17.05 \pm 1.11^{\mathrm{a}}$ & $17.78 \pm .83^{\mathrm{a}}$ & $18.61 \pm .46^{\mathrm{a}}$ & $18.58 \pm .91^{\mathrm{a}}$ \\
\hline
\end{tabular}

Means within the same row carrying different superscripts are significantly different at $(P \leq 0.05)$

Table 5: Effect of S. Platensis supplementation on antioxidant status of Nile tilapia muscle after feeding the experimental diets for 75 days.

\begin{tabular}{ccccc}
\hline & Sp0 & Sp0.5 & Sp1 & Sp1.5 \\
\hline MDA $(\mu \mathrm{mol} / \mathrm{gm})$ & $122.55 \pm 8.74^{\mathrm{a}}$ & $57.17 \pm 12.13^{\mathrm{b}}$ & $58.03 \pm 5.76^{\mathrm{b}}$ & $63.60 \pm 24.31^{\mathrm{b}}$ \\
GR $(\mathrm{ng} / \mathrm{gm})$ & $1.51 \pm 0.21^{\mathrm{c}}$ & $2.69 \pm 0.34^{\mathrm{b}}$ & $3.20 \pm 0.23^{\mathrm{b}}$ & $4.19 \pm 0.09^{\mathrm{a}}$ \\
\hline
\end{tabular}

Means within the same row carrying different superscripts are significantly different at $(P \leq 0.05)$

Table 6: Effect of S. Platensis supplementation on lysozyme, IgG, IgM values and catalase activity in serum of Nile Tilapia after feeding the experimental diets for 75 days.

\begin{tabular}{lllll}
\hline & \multicolumn{1}{c}{ Sp0 } & \multicolumn{1}{c}{ Sp0.5 } & \multicolumn{1}{c}{ Sp1 } & \multicolumn{1}{c}{ Sp1.5 } \\
\hline Lysozyme $(\mu / \mathrm{ml})$ & $3.94 \pm 0.04^{\mathrm{c}}$ & $5.10 \pm 0.52^{\mathrm{bc}}$ & $6.60 \pm 0.34^{\mathrm{ab}}$ & $7.28 \pm 0.71^{\mathrm{a}}$ \\
$\operatorname{IgG}(\mathrm{ng} / \mathrm{ml})$ & $46.66 \pm 7.37^{\mathrm{c}}$ & $81.15 \pm 15.65^{\mathrm{b}}$ & $108.47 \pm 21.67^{\mathrm{a}}$ & $132.62 \pm 6.84^{\mathrm{a}}$ \\
$\operatorname{IgM}(\mu \mathrm{g} / \mathrm{ml})$ & $5.53 \pm 0.18^{\mathrm{a}}$ & $5.83 \pm 0.80^{\mathrm{a}}$ & $6.61 \pm 0.86^{\mathrm{a}}$ & $6.77 \pm 1.57^{\mathrm{a}}$ \\
Catalase $(\mu \mathrm{mol} / / \mathrm{ml})$ & $40.58 \pm 11.70^{\mathrm{b}}$ & $65.93 \pm 8.41^{\mathrm{a}}$ & $68.89 \pm 6.91^{\mathrm{a}}$ & $48.69 \pm 6.91^{\mathrm{a}}$ \\
\hline
\end{tabular}

Means within the same row carrying different superscripts are significantly different at $(P \leq 0.05)$

significantly affected by S. Platensis supplementation (Table 6).

\section{DISCUSSION}

The results showed that supplementation with $S$. platensis up to $1.5 \%$ did not have negative impacts on growth performance in Nile tilapia. This finding is similar to that reported by Teimouri et al., (2013) who found that replacement of fishmeal with $\mathrm{S}$. platensis up to $10 \%$ did not decline growth rate on growth performance in rainbow trout. A tendency toward better growth performance at $1 \% \mathrm{~S}$. platensis observed in the current study suggests that, unlike plant ingredients, the inclusion of $S$. platensis as a feed additive may improve feed efficiency by increasing gut bacterial colonization Teimouri et al., (2013). James et al. (2006) suggested that $S$. platensis improves the intestinal flora in fish rendering break down of indigestible feed components to extract more nutrients from the feed; this also stimulates the production of enzymes that transport fats within the fish for metabolism instead of storage. Similarly, Ungsethaphand et al., 2010 that showed that the growth performance of hybrid red tilapia fed on $S$. platensis supplemented diets were not significantly differ. Our results showed no significant difference in 
DM, protein and ash content among treatments, but there was significant decrease in fat content between control group and other groups. Abdel-Latif and Khalil, (2014) showed that no significant differences among treatments for moisture, ash and lipid content, but the protein content in muscle of fish fed $10 \%$ spirulina diet was the highest.

The current study showed that feeding dietary S. platensis increased glutathione reductase, catalase activity and reduce MDA formation. The antioxidant activity of Spirulina has been very well documented by Abd El-Baky et al., 2006; Khan et al., 2005; Athukorela et al., 2006. A tendency toward increasing antioxidant enzymes and decreasing lipid peroxidation in S. platensis supplemented diets observed in the current study suggests that, among algal species, Spirulina has been reported to prevent oxidative damage by scavenging free radicals and active oxygen (Halliwell \& Gutteridge 1989; Kok et al 1990). Nitric oxide radical scavenging activities in the different algal extracts have been used as an indicator of antioxidant property of different algal extracts (Rojas et al., 1992). The results of Arun et al., (2012) revealed high percentage of NO scavenging activity in S. platensis. The antioxidant potential in the extract of Spirulina might be due to the total phycocyanin, triterpenoids and carotenoids present in the algal extracts. Estrada et al. (2001) demonstrated the antioxidant activity of the phycobiliproteins, phycocyanin and alophycocyanin present in Spirulina biomass. The current study showed that feeding dietary $S$. platensis increased lysozyme level. This finding was in accordance with (Ragap et al., 2012) who found that Spirulina - treated tilapia $(10 \mathrm{mg}$ / fish) recorded the highest levels of lysozyme compared with Spirulina - treated tilapia (1 mg / fish), vaccinated and control groups. Lysozyme, detected in the blood, mucus and organs of various fish, plays on important bactericidal role in the nonspecific defense against pathogens primarily through lytic actions on the pathogen cell wall. High lysozyme activity may be desirable in cultured fish because it may aid against infection when fish are kept at high densities and consequently are exposed to high bacterial loads (Grinde et al., 1988). Similarly, Ibrahem et al., (2013) concluded that $S$. platensis supplementation up to $10 \%$ increase lyzozyme level in Nile tilapia.

Our results showed that feeding dietary $S$. platensis increased level of IgG. This finding is similar to Hayashi et al., (1998) who reported that IgG antibody which was increased by antigen administration was further enhanced by Spirulina extract.

\section{Conclusion}

The results of present study demonstrated the potential of $S$. platensis as a feed additive to have no improving effect on Nile tilapia growth performance except for diet supplemented with $1 \%$ spirulina with apparent effects towards antioxidant defense and innate and humoral immunity status. S. platensis can also be supplemented in diet as an effective natural antioxidant source. Moreover, this study showed that S. platensis can be used as a fishmeal replacement in Nile tilapia diets due to its high protein content and no negative impacts on fish performance.

\section{REFERENCES}

Abd El-Baky, H.H., El Baz, F.K., El-Baroty, G.S. 2006. Over-production of Lipid Rich in $\gamma$ - Linolenic Acid by Blue Green Alga Spirulina maxima and its Inhibitory Effect on Carcinoma Cells. Ad FoodSci. 4: 206-212.52.

Abdel Latif, M. Hany and Khalil, H. Riad 2014. Evaluation of two phytobiotics, spirulina platensis and origanum vulgare extract on growth, serum antioxidant activities and resistance of Nile tilapia (Oreochromis niloticus) to pathogenic vibrio 
alginolyticus. Int. J. of Fisheries and Aquatic Studies, 1(5): 250-255

Amarl, D.M., Moreira, M., Lobato, M.A. and Abreu, S.M. 1995. Efeito inibidor de substâncias antioxidants existentes no vinho tinto na aterogênese experimental no coelho. Vittalle, 7: 17-24.

APHA (American Public Health Association) 1992. Standard methods for the examination of water and wastewater. 18th ed. APHA, Washington, DC.

Arun, N., Gupta, S. and Singh, D.P. 2012: Antimicrobial and antioxidant property of commonly found microalgae Spirulina platensis, nostoc muscorum and chlorella pyrenoidosa against some pathogenic bacteria and fungi. Int. J. of Pharm. Sci. \& research, 3(12): 4866-4875

Athukorala, Y., Nam, K., Jeon, Y. 2006. Antiproliferative and antioxida nt properties of an enzymatic hydrolysate from brown alga, Ecklonia cava. Food Chem. Toxicol. 44: 1065-1074.

Castell, J.D. and Tiewes, K. 1980. Report of the EIFAC, IUNS and ICES working group on the standardization of methodology in fish research, Hamburg, FRG, 21-23 March 1979. IFAC tech. Pap., 3(24).

Dernekbasi, S., Una, H., Karayucel, I. and Aral, O. 2010. Effect of dietary supplementation of different rates of Spirulina (Spirulina platensis) on growth and feed conversion in guppy (Poecilia reticulata Peters, 1860). Journal of Animal and Veterinary Advances 9: 1395-1399.

Duval, B. and Shetty, K. 2001. The stimulation of phenolics and antioxidant activity in pea (Pisum sativum) elicited by genetically transformed anise root extract. Journal of Food Biochemistry, 25: 361-377.

Estrada, J.E., Bescós, P. and Villar Del Fresno, A.M. 2001. Antioxidant activity of different fractions of Spirulina platensis protean extract. Il Farmaco, 56: 497-500.

Frankel, E.N., Waterhouse, A.L. and Teisseche, L.P. 1995. Principal phenolic phytochemicals in selected California wines and their antioxidant activity in inhibiting oxidation of human low-density lipoproteins. Journal of Food Chemistry, 43: 890894.

Giannenas, I., Tsalie, E., Chronis, E., Mavridis, S., Tontis, D., Kyriazakis, I., 2011. Consumption of Agaricus bisporus mushroom affects the performance, intestinal microflora composition and morphology, and antioxidant status of turkey poults. Animal Feed Science and Technology 165: 218-229.

Goth, L., 1991. A simple method for determination of serum catalase activity and revision of reference range. Clinica Chimica Acta 196: 143-151.

Grinde, B., Lie, O., Poppe T. and Salte, R. 1988. Species and individual variation in lysozyme activity in fish of interest in aquaculture. Aquaculture. 68: 299- 304.

Halliwell, B. and Gutteridge, J.M.C. 1989. Free Radicals in Biology and Medicine. 2nd edn. Clarendon Press, Oxford, pp. 299-357.12.

Hayashi, O., Hirahashi, T., Katoh, T., Miyajima, H., Hirano, T.D. and Oku waki Y. 1998. Class specific influence of dietary Spirulina platensis on antibody production in mice. J. Nutr. Sci. Vilaminol. 44: 481451.

Hironobu, W., Kazuki, O., Asmi, C., Tassakka, T. and Masahiro, S. 2006. Immunostimulant effects of dietary Spirulina platensis on carp, Cyprinus carpio. Aquaculture. 258: 157 - 163.

Ibrahem, D. Mai, Mohamed, M.F. \& Ibrahim, A. Marwa 2013. The Role of Spirulina platensis (Arthrospira platensis) in Growth and Immunity of 
Nile Tilapia (Oreochromis niloticus) and Its Resistance to Bacterial Infection. Journal of Agricultural Science; 5:6.

Jaime-Ceballos, B.J., Hernández-Llamas, A., Garcia-Galano, T. and Villarreal, H. 2006. Substitution of Chaetoceros muelleri by Spirulina platensis meal in diets for Litopenaeus schmitti larvae. Aquaculture 260: 215-220.

James, R., Sampath, K., Thangarathinam, R., Vasudevan, I. 2006. Effects of dietary Spirulina level on growth, fertility, coloration and leucocyte count in red swordtail, Xiphophorus helleri. Israeli Journal of Aquaculture-Bamidgeh 58(2): 97104.

Khan, M., Shobha, C.J., Rao, U.M., Sundaram, C.M., Singh, S., Mohan, J. I., Kuppusamy, P. and Kutala, K.V. 2005. Protective effect of Spirulina against doxorubicin-induced cardiotoxicity. Phytother. Res 19: $1030-1037$

Kok, F.J., Van Poppel, G., Melse, J., Merheul, E., Schouten, E.G., Kruyssen, E.H, Hofman, A. 1990. Antioxidant and polyunsaturated acids have a combined association with coronary atherosclerosis. Atherosclerosis. 86: 85-90

Lie, O., Evensen, P.I., Sorensen, A. and Froysadal, E. 1989. Study on lysozyme activity in some fish species. Diseases of Aquatic Organisms 6: 1-5.

Milié, B.L., Djilas, S.M. and Canadavnovié-Brunet, J.M. 1998. Antioxidative activity of phenolic compounds on the metal-ion breakdown of lipid peroxidation system. Food Chemistry, 61:443-447.

Miranda, M.S., Cintra, R.G., Barros, S.B.M. and Filho, J.M. 1998. Antioxidant activity of the microalga Spirulina maxima. Brazilian Journal of Medical and Biological Research, 31: 1075-1079.
Mustafa, M.G. and Nakagawa, Y.H. 1995. A review: Dietary benefits of algae as an additive in fish feed. Isr. J. Aquacult. 47: 155-162.

Mustafa, M.G., Takeda, T., Umino, T., Wakamatsu, S. and Nakagawa, H. 1994. Effects of Ascophyllum and Spirulina meal as feed additives on growth performance and feed utilization of red sea bream, Pagrus major. Journal of the Faculty of Applied Biological Science. Hiroshima University 33: 125-132.

Nandeesha, M., Gangadhara, B., Manissery, J., Venkataraman, L. 2001. Growth performance of two Indian major carps, catla (Catla catla) and rohu (Labeo rohita) fed diets containing different levels of Spirulina platensis. Bioresource Technology 80: 117-120.

NRC, National Research Council 1993. Nutrition requirements of fish. National Academic Press, Washington, DC.

Promya, J., Chitmanat, C. 2011. The effects of Spirulina platensis and Cladophora algae on the growth performance, meat quality and immunity stimulating capacity of the African sharp tooth catfish (Clarias gariepinus). International Journal of Agriculture and Biology 13: 77-82.

Ragap, H.M., Khalil, R.H. and Mutawie, H.H. 2012. Immunostimulant effects of dietary Spirulina platensis on tilapia "Oreochromis niloticus". Journal of Applied Pharmaceutical Science 02(02): 26-31.

Recker, W.E. 1975. Computation and interpretation of biological statistics of fish population. Fish Res. Borard Can. Bull.,191.

Rojas, A., Hernandez, L., Pereda, M.R., Mata, R. 1992. Screening for antimicrobial activity of crude drug extracts and pure natural products from Mexican medicinal plants. J Ethnopharmacol. 35: 275-283.51. 
Santiago, C., Banesaldaba, M. and Laron, M. 1982. Dietary crude protein requirement of tilapia-nilotica-fry. Kalikasan-the philipp.J.Biol., 11: 255-265.

Stuart, J.S. and Hung, S.S.O. 1989. Growth of juvenile white sturgeon (acipenser transmontanus) fed different proteins. J. Aquaculture. 76: 303-316.

Takeuchi, T.J., Lu, G., Yoshizaki, Y., and Satoh, S. 2002. Effect on the growth and body composition of juvenile tilapia Oreochromis niloticus fed raw Spirulina platensis. Fish Sci., 68: 3440.

Teimouri, M., Amirkolaie, A.K., Yeganeh, S. 2013. The effects of Spirulina platensis meal as a feed supplement on growth performance and pigmentation of rainbow trout (Oncorhynchus mykiss). World Journal of Fish and Marine Sciences 5(2): 194-202.
Ungsethaphand, T., Peerapornpisal, Y., Whangchai, N. and Sardsud, U. 2010. Effect of feeding Spirulina platensis on growth and carcass composition of hybrid red tilapia (Oreochromis mossambicus $\times O$. niloticus). Maejo Int. J. Sci. Technol. 4(02): 331-336.

Yen, G.C. and Chen, H.Y. 1995. Antioxidant activity of various tea extracts in relation to their antimutagenicity. Journal of Agricultural and Food Chemistry, 43: 27-32.

Yoshino, M. and Murakami, K. 1995. Interaction of iron with polyphenolic compounds: application to antioxidant characterization. Analytical Biochemistry, 257: 40-44.

Zehra, S. and Khan, M.A. 2011. Dietary protein requirement for fingerling Channa punctatus (Bloch), based on growth, feed conversion, protein retention and biochemical composition. J. Aquaculture Int. 